\title{
Fish diet and male reproductive hormones in albino rats
}

\author{
O. S. Serag El Din, Batta H. Abd El Azim and Rania A. Lotfy*
}

\begin{abstract}
Background: Fish, a widely claimed healthy food for humans, could also pose problems to health due to accumulation of pollutants, especially heavy metals and pesticides. Since the world's fish stocks are limited due to overfishing, degraded freshwater, and pollution from various sources, the government proposed farmed fish which is one of the fastest growing food production sectors as an alternative.

The objective of this study was to investigate the effects of tilapia or Mugil cephalus fish diets obtained from polluted areas on male reproductive hormones and prolactin. A total of 80 male Wister albino rats having an average weight of 130-150 $\mathrm{g}$ at the beginning of the experiment were used. They were divided into control group and seven treated groups which received the following doses that increased monthly according to the increase in rat body weight (b.w.). The treated groups received $200 \mathrm{~g} / 70 \mathrm{~kg}$ human b.w. which is equivalent to $0.4 \mathrm{~g} / 140 \mathrm{~g}$ rat b.w., $0.63 \mathrm{~g} / 220 \mathrm{~g}$ rat b.w., and $0.83 \mathrm{~g} / 291 \mathrm{~g}$ rat b.w. of tilapia fish (wild and farmed freshwater and brackish water) or Mugil cephalus fish (farmed freshwater and brackish water and wild marine water) daily for 3 months then were left on AIN-93M diet and purified water ad libitum.
\end{abstract}

Results: The present results demonstrated that tilapia and Mugil cephalus fish diets caused decrease in serum total testosterone, follicle-stimulating hormone, luteinizing hormone, and sperm count, while sperm abnormalities significantly increased. Also, significant elevation of serum prolactin was observed in male rats fed with the same diets except wild brackish water tilapia fish and farmed freshwater and brackish water Mugil cephalus fish diets which showed a decrease. However, tilapia and Mugil cephalus fish diets had no effect on serum 17ß-estradiol. The histopathological studies confirmed biochemical data as less dense packing of spermatogenic cell of the seminiferous tubules with reduction in the number of sperms in lumen of the epididymal tubules.

Conclusions: These results may indicate that consumption of tilapia and Mugil cephalus fish diets from polluted areas has adverse effects on male reproductive hormones and prolactin in male albino rats.

Keywords: Wild fish, Farmed fish, Pollutants, Male reproductive hormones, Prolactin

\section{Background}

Fish is a dynamic source of food for people worldwide. Consuming fish provides an important source of proteins, polyunsaturated fatty acids (PUFAs), liposoluble vitamins, and essential minerals, which are associated with health and normal growth (Wim, Issabelle, Stefan, \& John, 2007). Drawing on such evidence, the global demand for seafood products is continuing to increase dramatically, but wild fish stocks are being depleted rapidly due to overfishing, degraded freshwater, pollution from various sources, illegal fishing operations of fry, and

* Correspondence: rania_ata_2008@yahoo.com

Zoology Department, Faculty of Women for Art, Science \& Education, Ain Shams University, Cairo, Egypt

(c) The Author(s). 2018 Open Access This article is distributed under the terms of the Creative Commons Attribution 4.0 International License (http://creativecommons.org/licenses/by/4.0/), which permits unrestricted use, distribution, and reproduction in any medium, provided you give appropriate credit to the original author(s) and the source, provide a link to the Creative Commons license, and indicate if changes were made. relaxation in the implementation of laws and regulations (Rothuis et al., 2013). Therefore, as an alternative fish source, aquaculture is probably the fastest growing food-producing sector in the world (FAO, 2014) and it has a great potential to meet the growing demands for seafood and animal protein (Yue, Lin, \& Li, 2016). Today, most fish consumed globally by people comes from aquaculture (FAO, 2014).

However, some concerns about potential health hazards derived from pollution found in fish have also been raised. Therefore, the adequate balancing of the risks and benefits of fish consumption is currently a nutritional and environmental health key issue (Domingo, 2007). A wide range of toxic substances are present in the aquatic environment 
such as heavy metals and pesticides which are produced by human activities (through the discharge of agricultural, municipal, residential, or industrial waste products), and they can accumulate in the muscles of fish (Maier et al., 2014; Petkovšek, Grudnik, \& Pokorny, 2012). Consequently, recurrent fish meat consumption may allow high amounts of toxicants to enter the human body, to accumulate in tissues and to generate chronic toxicity, which inter-affects the male reproductive system and may lead to decreased fertility (Gdoura et al., 2011).

As for aquaculture, rearing of fish is practiced in ponds which are fertilized with manure fertilizers (chicken manure and cattle manure) and chemical fertilizers (urea and super phosphate) to allow production up to 2000 to $3000 \mathrm{~kg} /$ hectare/crop. In addition, the fish larvae are fed with feeds that are incorporated with the synthetic steroid $17 \alpha$-methyl testosterone (17 $\alpha$-MT) which is a male-specific hormone commonly used to induce sex reversal in farmed fish at a concentration of $60 \mathrm{mg} / \mathrm{kg}$ of feed (Zheng et al., 2016). 17 $\alpha$-MT treatment results in a final size of fish $10.7 \%$ larger and more uniform size than mixed sex fish (Ahmad, Shalaby, Khattab, \& Abdel-Tawwab, 2002). Rizkalla, Haleem, Abdel-Halim, and Youssef (2004) found that whole-body samples of normal fish and those treated for 28 days with $17 \alpha-\mathrm{MT}$ contained detectable amounts of testosterone only in the first 5 months after the termination of feeding. Rivero-Wendt et al. (2014) showed that higher levels of $17 \alpha$-MT produced some testicular degeneration.

In water resources in aquaculture, although aquaculture is a major industry, the sector is not allowed to use irrigation by Nile water and is generally dependent on groundwater and agricultural drainage channels that are contaminated with pesticides and other harmful compounds such as heavy metals (Naziri, 2011). But the majority of farmers use natural water resources such as Nile water and lake water that are contaminated with industrial, domestic, and agricultural drainage and sewage.

Aravindakshan, Gregory, Marcogliese, Fournier, and Cyr (2004) said that feeding male rats with contaminated fish could alter the development of their reproductive systems. Also, Gdoura et al. (2011) showed that feeding male rats with muscle wild tuna fish for 60 days lowered testosterone level and number and motility of spermatozoa and caused an atrophy of the genital tract, including the testes, epididymis, prostate, and seminal vesicles. Moreover, Risso, Pellegrino, Relling, and Corrada (2016) noted that supplementation of $54 \mathrm{mg} / \mathrm{kg}$ fish oil for 120 days decreased serum testosterone concentrations in male dogs. On the other hand, Afeiche et al. (2014) cited that consuming dark fish, white fish, or shellfish could have a beneficial effect on sperm count and morphology, particularly when consumed instead of processed red meats in men. Yet, Persky et al. (2001) found that consumption of wild salty water fish (salmon, trout, carp, and catfish) had no significant effects on testosterone, follicle-stimulating hormone (FSH), and luteinizing hormone (LH) in men. Also, Yeste, Barrera, Coll, and Bonet (2011) showed that dietary tuna oil had no effect on sperm count, motility, and viability in boars when compared with the control group.

\section{Methods}

\section{Experimental animal design}

Eighty male Wister albino rats, weighing between 130 and $150 \mathrm{~g}$ at the beginning of the experiment were used in the current study. The animals were housed in the vivarium of the animal house of the Faculty of Women, Ain Shams University. They lived in an environmentally controlled laboratory upon arrival and acclimatized for 1 week before the onset of the experiment; they were kept in cages and provided with vegetables and purified water ad libitum.

Following this week of adaptation, rats were divided into control group and seven treated groups which received the following doses that increased monthly according to the increase in rat b.w.:- first month: rats with an average b.w. $140 \mathrm{~g}$ received $0.4 \mathrm{~g}$ grilled fish diet; second month: rats with an average b.w. 220 g received $0.63 \mathrm{~g}$ grilled fish diet; and third month: rats with an average b.w. $291 \mathrm{~g}$ received $0.83 \mathrm{~g}$ grilled fish diet. These doses correspond to $200 \mathrm{~g} / 70 \mathrm{~kg}$ human b.w.

The groups were organized as follows:

a) Control group $(n=10)$ : rats were fed with basal diet (AIN-93M) and purified water ad libitum for 3 months.

b) First treated group $(n=10)$ : each rat was fed individually daily for 3 months with grilled wild fresh water tilapia fish obtained from the Moyes Sea, El-Sharqia governorate, which is polluted by industrial and agricultural drainage water and sewage water.

c) Second treated group $(n=10)$ : each rat was fed individually daily for 3 months with grilled farmed freshwater tilapia fish obtained from a farm in Kafr El-Sheikh governorate which is polluted by agricultural drainage water (Authman, 2008).

d) Third treated group $(n=10)$ : each rat was fed individually daily for 3 months with grilled wild brackish water tilapia fish obtained from Lake ElManzalah, Damietta governorate, which is polluted by industrial, domestic, and agricultural drainage water (Ali, 2008).

e) Fourth treated group $(n=10)$ : each rat was fed individually daily for 3 months with grilled farmed brackish water tilapia fish obtained from a farm in Damietta depending on Lake El-Manzalah which is 
polluted by industrial, domestic, and agricultural drainage water (Ali, 2008).

f) Fifth treated group $(n=10)$ : each rat was fed individually daily for 3 months with grilled farmed fresh water Mugil cephalus fish obtained from a farm in Kafr El-Sheikh governorate which is polluted by agricultural drainage water (Authman, 2008).

g) Sixth treated group $(n=10)$ : each rat was fed individually daily for 3 months with grilled wild marine water Mugil cephalus fish obtained from the Suez Canal which is polluted by oil pollution and heavy metals (Kelly et al., 2008).

h) Seventh treated group $(n=10)$ : each rat was fed individually daily for 3 months with grilled farmed brackish water Mugil cephalus fish obtained from a farm in Damietta depending on Lake El-Manzalah which is polluted by industrial, domestic, and agricultural drainage water (Ali, 2008).

All seven treated groups after eating the fish diet were then given basal diet (AIN-93M) (according to Reeves, Nielson, \& Fahey, 1993) and purified water ad libitum.

\section{Fish diets}

Fish farming in Egypt is mainly based on the production of tilapia (75.54\%) with Mugil cephalus (12.74\%), the most important species on private fish farms (Macfadyen et al., 2011). Tilapia and Mugil cephalus fish mainly inhabit rivers and marines and are less commonly found living in brackish water such as lakes. Sample preparation and cooking were done according to Lorenzini et al. (2012).

\section{Serum sample collection}

At the end of each experiment, blood was withdrawn from the orbital plexus or cardiac puncture, and serum was separated to be used for the determination of the following parameters:

1. Determination of total testosterone by enzymelinked immunosorbent assay (ELISA) kits according to Turkes et al. (1979).

2. Determination of $17 \beta$-estradiol $\left(\mathrm{E}_{2}\right)$ by ELISA kits according to Sadem, Sela, and Hexter (1979).

3. Determination of FSH by ELISA kits according to Rose (1998).

4. Determination of LH by ELISA kits according to Rebar, Erickson, and Yen (1982).

5. Determination of prolactin by ELISA kits according to Goffin, Binart, Touraine, and Kelly (2002).

\section{Semen analysis}

\section{Sperm count assay}

The sperms were counted using a hemocytometer following the methodology of Pant and Srivastava (2003).

\section{Sperm abnormalities}

Sperm abnormalities were evaluated using an eosin and nigrosin stain according to the method of Bjorndahi, Söderluund, and Kvist (2003).

\section{Histopathological studies}

The testis and epididymis were obtained and cleaned from adhering tissues then fixed in $10 \%$ formal saline for $24 \mathrm{~h}$ and staining with hematoxylin and eosin (H\& E) according to Banchroft, Stevens, and Turner (1996).

\section{Statistical analysis}

All data were analyzed using the Statistical Processor System Support (SPSS) for windows software, version 16.0. Analysis of variance (one-way ANOVA) was performed to test for any significant differences among groups, and independent sample $T$ test was used to calculate statistical significance between groups. The level of significance was set as $P<0.05$ for all statistical tests.

\section{Results}

The data present in Table 1 show the effect of grilled tilapia fish diets fed for 3 months on serum reproductive hormones, prolactin, sperm count, and sperm abnormalities of male albino rats.

The present study showed significant reduction in serum levels of total testosterone, $\mathrm{FSH}$, and sperm count in male rats fed with wild and farmed freshwater and brackish water tilapia fish with $-36.18 \%,-42.32 \%$, $37.20 \%$, and $-47.78 \%$ for total testosterone; $-47.92 \%$, $42.71 \%,-71.88 \%$, and $-53.13 \%$ for $\mathrm{FSH}$; and $-23.18 \%$, $-40.35 \%,-22.71$, and $-31.29 \%$ for sperm count respectively. Serum level of $\mathrm{LH}$ in male rats fed with wild and farmed brackish water tilapia fish significantly decreased with $-61.64 \%$ and $-61.64 \%$ respectively. Whereas, significant elevation of serum prolactin was observed in male rats fed with grilled wild and farmed freshwater and farmed brackish water tilapia fish with $23.73 \%, 35.59 \%$, and $55.93 \%$, respectively, while male rats fed only with wild brackish water tilapia fish showed significant decrease of serum prolactin with $-32.20 \%$. Also, sperm abnormalities significantly increased in rats fed with wild and farmed fresh water and brackish water tilapia fish with $50.07 \%, 68.21 \%, 59.21 \%$, and $86.49 \%$ respectively. However, tilapia fish diet had no effect on serum $17 \beta-E_{2}$.

Comparing rats fed with wild with farmed fresh water tilapia fish, no significant changes were recorded in these parameters.

Comparing rats fed with wild with farmed brackish water tilapia fish and male rats fed with farmed brackish water tilapia fish showed significant increase of serum FSH and prolactin with $66.67 \%$ and $130 \%$ respectively. 


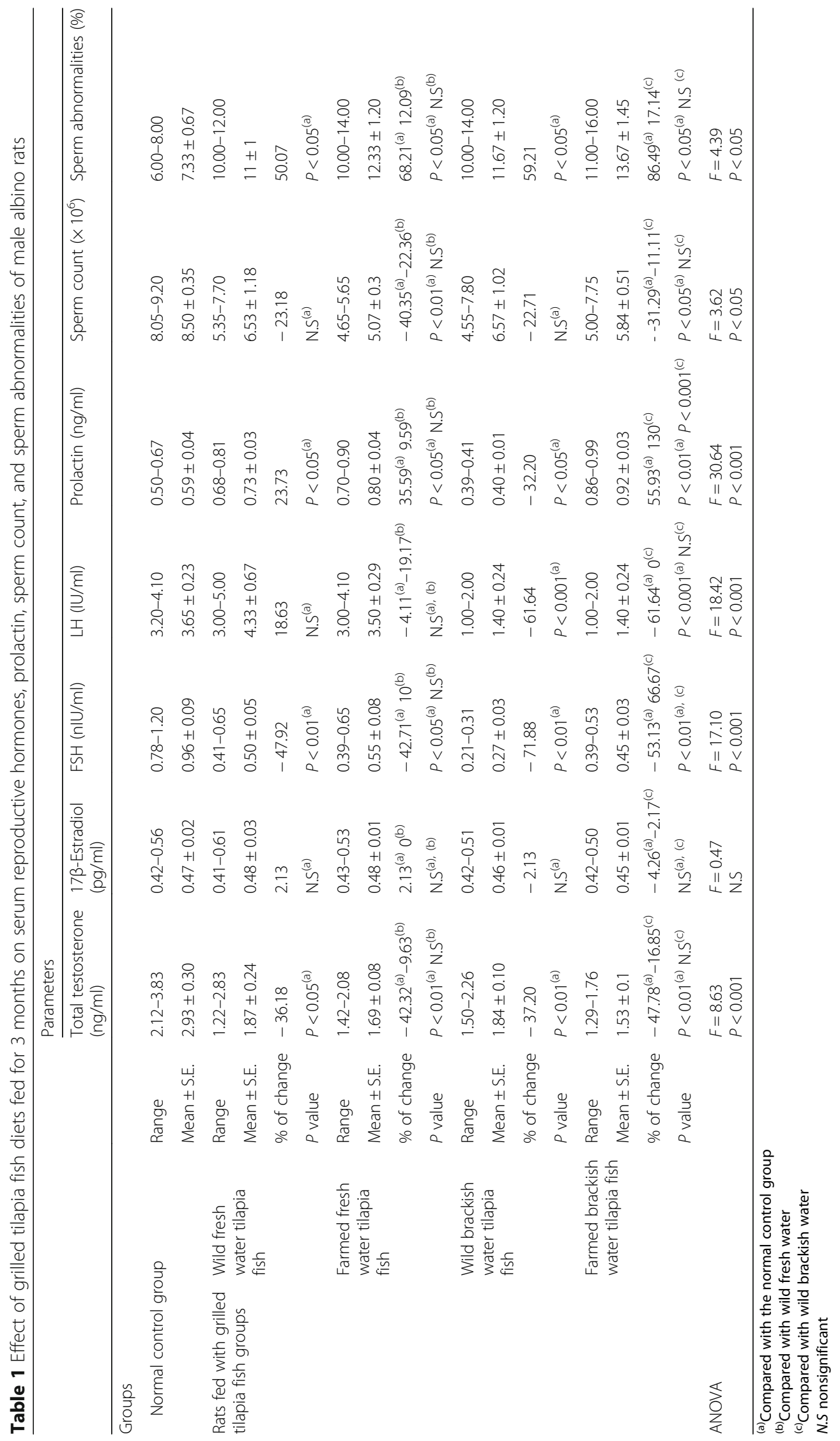




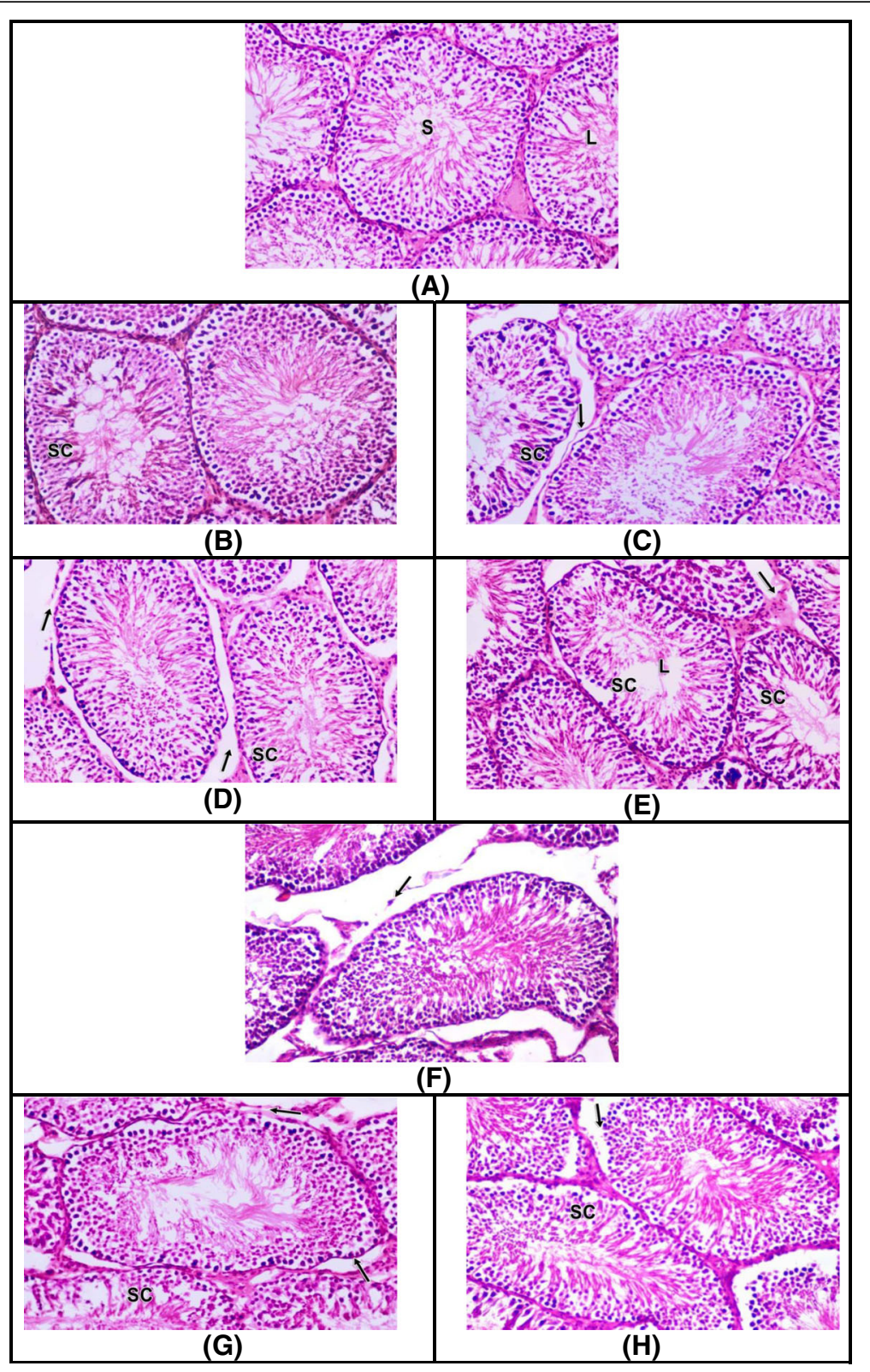

Fig. 1 a Photomicrograph of control testis showing normal histological structure of the seminiferous tubules with complete spermatogenic series (S) and small lumen $(L)$ densely filled up with sperms (H\&E $\times 200)$. $\mathbf{b}$ Photomicrograph of testis of the first treated group showing less dense packing of spermatogenic cell (SC) (H\&E $\times 200)$. c, d Photomicrographs of testis of the second and third treated groups showing splitting of basement membrane (arrow) and less dense packing of spermatogenic cell (SC) in some seminiferous tubules (H\&E $\times 200$ ). e Photomicrograph of testis of the fourth treated group showing splitting of basement membrane (arrow) and less dense packing of spermatogenic cell (SC) with wide emptied lumen (L) (H\&E $\times 200)$. $\mathbf{f}$ Photomicrograph of testis of the fifth treated group showing splitting of basement membrane of seminiferous tubules (arrow) (H\&E $\times 200)$. $\mathbf{g}$, h Photomicrographs of testis of the sixth and seventh treated groups showing splitting of basement membrane (arrow) and less dense packing of spermatogenic cell (SC) in some seminiferous tubules (H\&E $\times 200$ )

Histopathological studies showed that grilled tilapia fish diets induced splitting of basement membrane of seminiferous tubules and less dense packing of spermatogenic cell with wide emptied lumen as seen in Fig. 1b-e. As for the effect of grilled tilapia fish diets on the histology of epididymis, the present study showed columnar lining epithelium of the epididymal tubules with reduction in the number of sperms as seen in Fig. 2b-e. Also, grilled tilapia fish diets showed elevation in sperm abnormalities as increased number of quasi-normal head, big head, big head with coiled tail, amorphous head, banana-shaped head, hookless head, vacuolated head, detached head, and bent with projection filament and neck sperms as seen in Fig. 3b-h. 


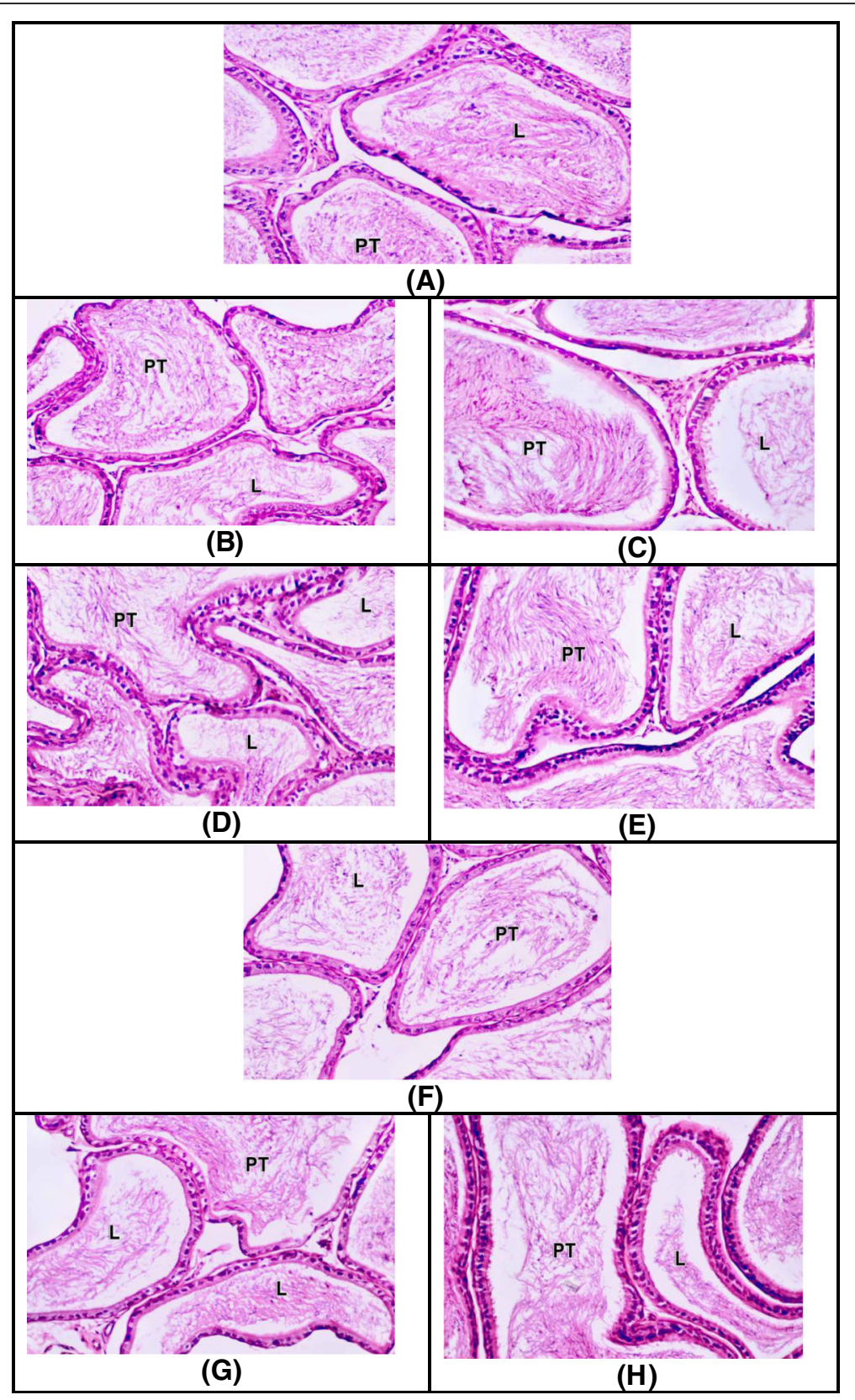

Fig. 2 a Photomicrograph of control epididymis showing normal histological structure of the epididymal tubules (PT) with lining columnar epithelium (arrow) and lumen impacted by sperms (L) (H\&E × 200). b-e Photomicrographs of epididymis of the first, second, third, and fourth treated groups showing columnar lining epithelium of the epididymal tubules (PT) with reduction in the number of sperms in lumen (L) (H\&E $\times$ 200). $\mathbf{f}-\mathbf{h}$ Photomicrographs of epididymis of the fifth, sixth, and seventh treated groups showing columnar lining epithelium of the epididymal tubules (PT) with large reduction in the number of sperms in lumen $(L)(H \& E \times 200)$

Data present in Table 2 show the effect of grilled Mugil cephalus fish diets fed for three months on serum reproductive hormones, prolactin, sperm count, and sperm abnormalities of male albino rats.

Male rats fed with farmed freshwater Mugil cephalus fish showed significant decrease of serum total testosterone and prolactin with $-32.76 \%$ and $-49.15 \%$ respectively compared with the control group. Serum level of
FSH and sperm count in male rats fed with farmed freshwater and brackish water and wild marine water Mugil cephalus fish significantly decreased with $56.25 \%,-73.96 \%$, and $-68.75 \%$ for FSH and $-25.88 \%$, $-41.06 \%$, and $-31.76 \%$ for sperm count respectively. Serum level of $\mathrm{LH}$ in male rats fed with farmed fresh water and wild marine water Mugil cephalus fish slightly decreased with $-4.11 \%$ and $-1.37 \%$ respectively, while 


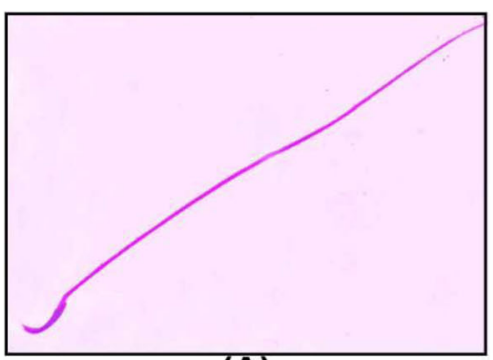

(A)

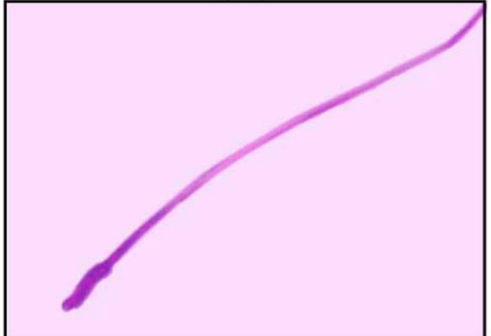

(C)

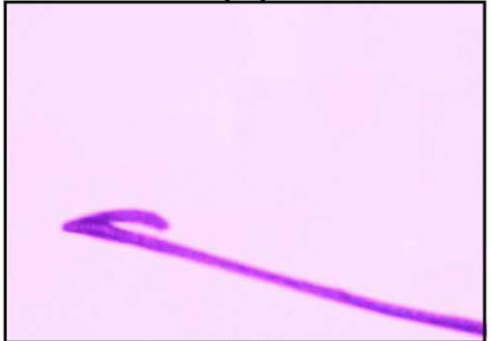

(E)

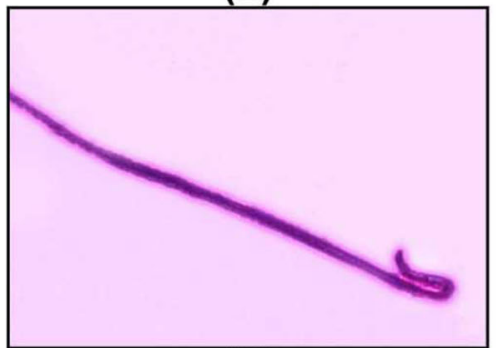

(G)

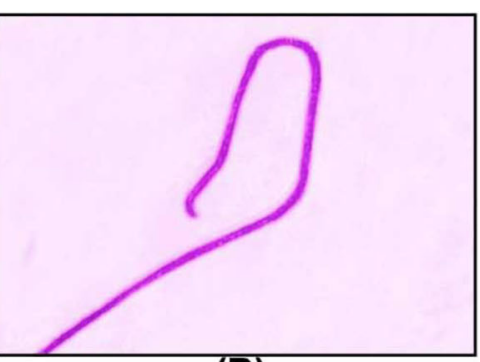

(B)

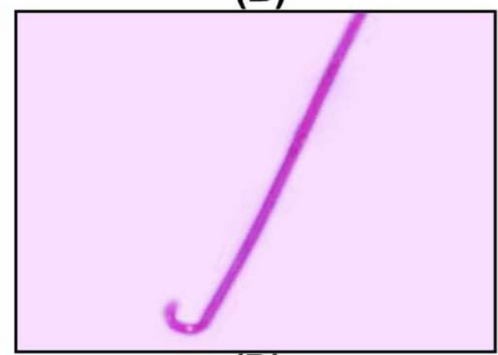

(D)

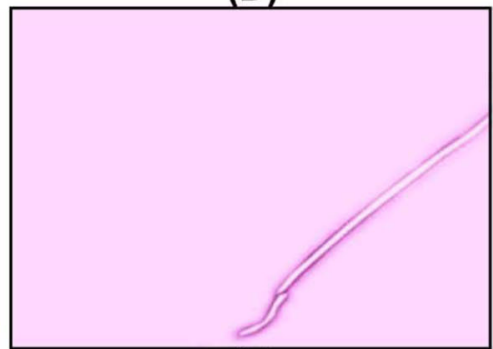

(F)

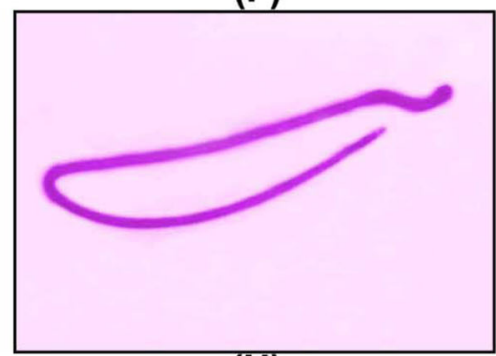

(H)

Fig. 3 Photomicrograph of different sperm abnormalities of rats fed with grilled tilapia fish showing a normal sperm, $\mathbf{b}$ quasi-normal head, $\mathbf{c}$ amorphous head, $\mathbf{d}$ vacuolated head, e detached head, $\mathbf{f}$ hookless head, $\mathbf{g}$ bent with projection filament and tail, and $\mathbf{h}$ big head with coiled tail $(E \& N \times 400)$

male rats fed only with farmed brackish water Mugil cephalus fish showed non-significant increase of serum LH with $27.95 \%$, whereas sperm abnormalities significantly increased in rats fed with the same groups with $97.82 \%, 113.78 \%$, and $111.46 \%$ respectively. However, Mugil cephalus fish diet had no effect on serum17 $\beta-\mathrm{E}_{2}$.

Comparing rats fed with wild marine water with farmed brackish water Mugil cephalus fish, male rats fed with farmed brackish water Mugil cephalus fish showed significant reduction of serum prolactin with $-31.88 \%$.

Histopathological studies showed that grilled Mugil cephalus fish diets induced splitting of basement membrane of seminiferous tubules with less dense packing of spermatogenic cell as seen in Fig. 1f-h. As for the effect of grilled Mugil cephalus fish diets on the histology of epididymis, the present study showed columnar lining epithelium of the epididymal tubules with large reduction in the number of sperms as seen in Fig. $2 \mathrm{f}-\mathrm{h}$. Also, grilled Mugil cephalus fish diets showed elevation in sperm abnormalities as increased number of quasi-normal head with coiled tail, banana-shaped head with coiled tail, hookless head, vacuolated head, deformed orientation head, acute curvature head, triangular head with coiled tail, and detached head sperms as seen in Fig. 4. 


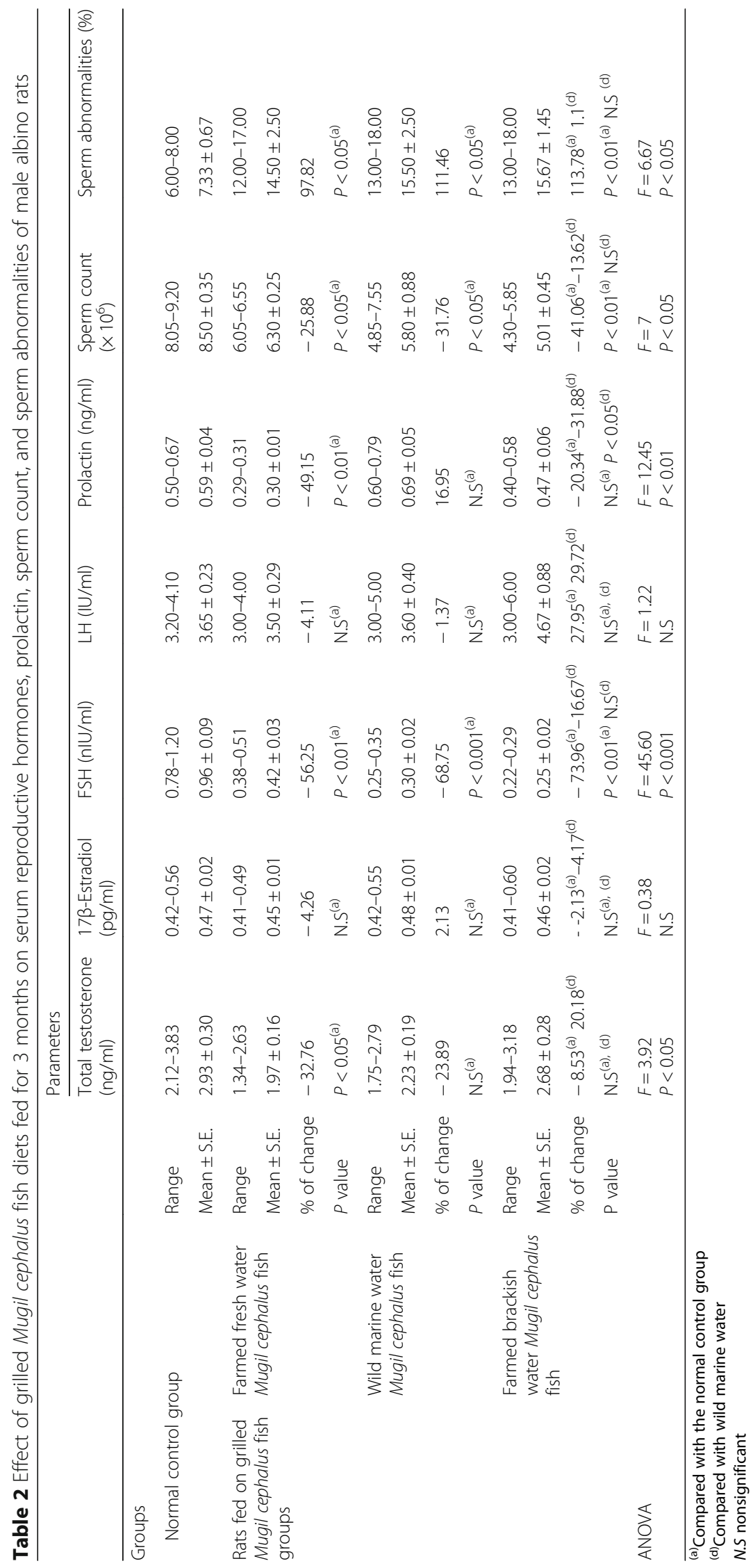




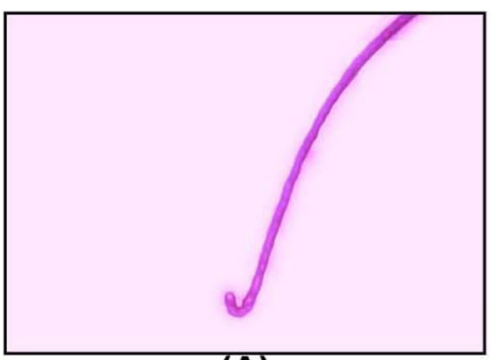

(A)

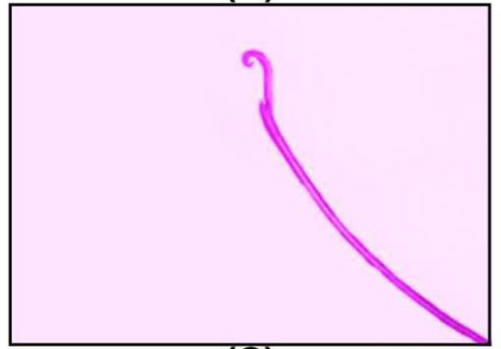

(C)

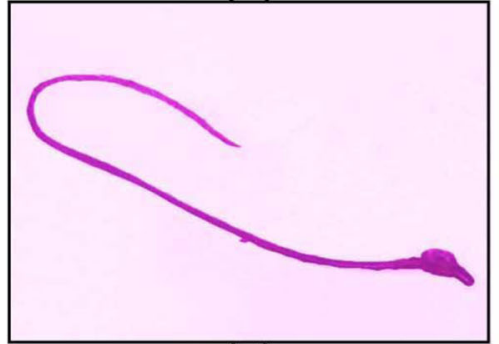

(E)

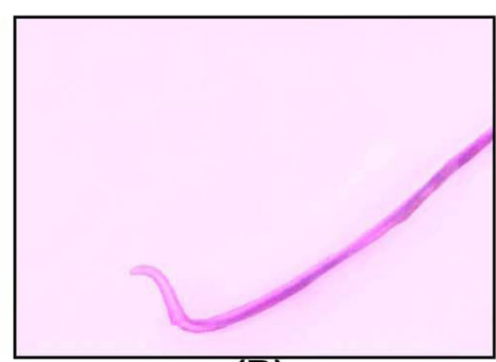

(B)

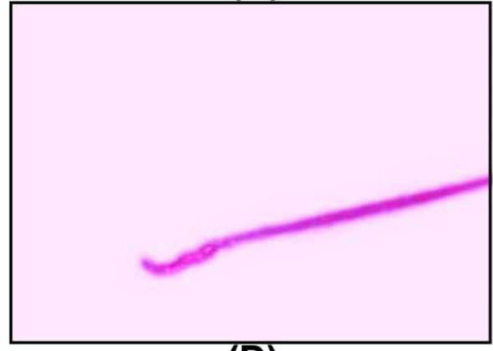

(D)

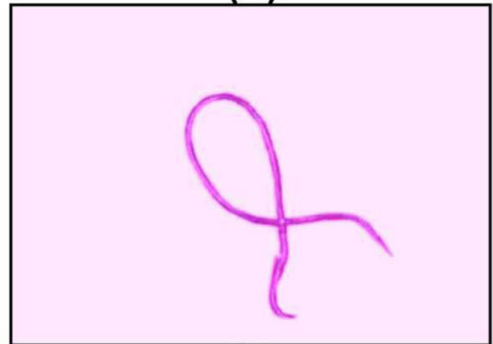

(F)

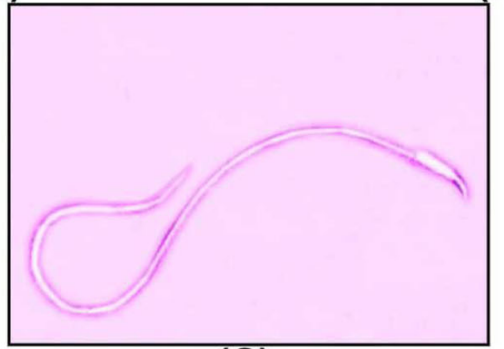

(G)

Fig. 4 Photomicrograph of different sperm abnormalities of rats fed with grilled Mugil cephalus fish showing a vacuolated head, b hookless head, $\mathbf{c}$ acute curvature head, $\mathbf{d}$ deformed orientation head, e triangular head with coiled tail, $\mathbf{f}$ quasi-normal head with coiled tail, and $\mathbf{g}$ banana-shaped head with coiled tail $(E \& N \times 400)$

\section{Discussion}

The present results demonstrated that male rats fed with grilled tilapia and Mugil cephalus fish diets showed decrease of serum total testosterone and FSH as well as a decrease in serum LH in male rats fed with the same diets except grilled wild freshwater tilapia fish and farmed brackish water Mugil cephalus fish diets which showed a non-significant increase.

These results agree with the study which found significant decrease in serum level of testosterone after consumption of wild tuna muscle from the Gulf of Gabes in the Tunisian coast which is known to be polluted by industrial wastes daily for 60 days in male rats (Gdoura et al., 2011). Also, Bolawa, Gbenle, and Ebuehi (2014) showed that ingestion of $100 \mathrm{~g}$ of tilapia fish from heavily polluted river sites (Carter Bridge and Makoko Riverine) for 3 months lowered FSH level while LH level increased in rabbits.

A possible explanation for the lowering of serum total testosterone may be due to the ability of heavy metals especially arsenic $(0.4 \mathrm{ppm} /$ day) to decrease activity of $17 \beta$-hydroxysteroid dehydrogenase $(17 \beta-H S D)$, the enzyme involved in the conversion of androstenedione to testosterone (Chattopadhyay, Ghosh, Chaki, Debnath, \& 
Ghosh, 2000). Also, lead (Pb) inhibits steroid production of both Sertoli and Leydig cells at every step of synthesis; expression and/or activity of gonadotrophin receptors, steroid acute regulator (StAR), p450 side chain cleavage, $3 \beta$ HSD, and P450c17, the enzyme that converts progesterone into testosterone, is significant if not dramatically suppressed by $\mathrm{Pb}$ in vivo, ex vivo, or in vitro (Liu, Leu, Yang, \& Huang, 2003).

Another interpretation may be due to the ability of mercury $(\mathrm{Hg})$ when given to rats for 90 days to suppress testicular steroidogenesis at the $3 \beta$-HSD synthetic step with a significant decrease in serum testosterone and $\mathrm{LH}$ (Nagar \& Bhattacharya, 2001; Ramalingam, Vimaladevi, Rajeswary, \& Suryavathi, 2003). In addition, oral exposure of rats to $\mathrm{Hg}(0.5 \mathrm{mg} / \mathrm{kg}$ b.w. $)$ for 45 days resulted in suppressed testosterone and increased testicular cholesterol (Rao \& Sharma, 2001; Tong, Christenson, \& Song, 2004). They also suggested that the increased testicular cholesterol is due to the block of its biosynthetic conversion to sex steroid hormones such as testosterone.

Webb et al. (2006) found significant negative correlations between serum testosterone and $\mathrm{Hg}$ content. The obtained results suggested the ability of $\mathrm{Hg}$ to disrupt endogenous hormone levels. In addition, environment pollutants in fish mimic sex hormones by binding to androgen receptors. Alternatively, they can block, prevent, and alter androgen binding to AR (Hedayati, Zare, \& Abarghouei, 2012).

Another explanation for the reduction of male sex hormone is the use of omega- $6(\omega-6)$ which is present in soy meal instead of fish meal in aquaculture; $\omega-6$ decreases steroidogenesis through direct effects on StAR and cytochrome P450, which play a critical role in regulating steroid synthesis (Stocco, Wang, Jo, \& Manna, 2005; Wathes, Abayasekara, \& Aitken, 2007).

Also, a possible explanation for the reduction of serum FSH and LH may be due to the exposure to $\mathrm{Pb}$ which suppressed FSH levels than the control group indicating an effect of $\mathrm{Pb}$ at pituitary FSH level (Marie, Lars, \& Anital, 2001). Moderate exposure to $\mathrm{Pb}$ was associated with minor changes in the male endocrine function particularly affecting the hypothalamic-pituitary axis (Lafuente, Carrace, Romero, \& Gano, 2005). In addition, Bolawa et al. (2014) confirmed the fact that heavy metals together with other environment pollutants (pesticides and $\mathrm{PCBs}$ ) are endocrine disruptors since they interfere with the level of FSH. As the level of environment pollutant increases, the levels of FSH decrease greatly.

Shokr (2015) said that exposure to 2, 4, and $8 \mathrm{mg} / \mathrm{l}$ of $\mathrm{Pb}$ levels for periods of 10 days, 20 days, and 30 days decreased serum testosterone, FSH, and LH levels by increasing the time exposure than the control group. So, heavy metal exposure can effectively decrease androgenic secretion. These results show a direct effect of metal contamination on steroidogenesis, which could be due to the harmful effects of metals on the hypothalamic-pituitary axis.

A possible explanation for the non-significant increase of LH in grilled wild freshwater tilapia fish and farmed brackish water Mugil cephalus fish may be due to the stronger effect of fish oil $\omega-3$ as inducer of the hypothalamic-pituitary axis to increase LH levels through the inhibition of hypothalamus neuropeptide $\mathrm{Y}$ production (Encinias, Pateel, \& Poland, 2007).

The current study showed elevation in serum prolactin hormone in male rats fed with grilled tilapia and Mugil cephalus fish diets except grilled wild brackish water tilapia fish and farmed freshwater and brackish water Mugil cephalus fish diets which showed decrease. These results agree with Lafuente, Cano, and Esquifino (2003) who found that oral exposure to higher dose of cadmium $(\mathrm{Cd})$ for 1 month decreased plasma prolactin hormone levels whereas increased plasma level of prolactin hormone was found with the lower dose of $\mathrm{Cd}$ in adult male rats. They added that a higher dose of Cd may act directly on the lactotrophs, through an interaction with the prolactin molecule that is sensitive to divalent metals, thus inhibiting its secretion. But the increase of prolactin in serum may be related to the inhibition of the immune response described after low doses of the metal, as subchronic elevation of prolactin may inhibit this system. So, the effect of $\mathrm{Cd}$ on prolactin seemed to be dose dependent.

Also, Lafuente et al. (2005) studied the effect of Cd on prolactin secretion in rats and observed that the $\mathrm{Cd}$-exposed animals exhibited variations in plasma prolactin levels. In addition, Bolawa et al. (2014) found that $\mathrm{Cd}$ is associated with deleterious effect on the gonadal function and with changes in the secretory pattern of other pituitary hormones like prolactin and TSH.

Grilled tilapia and Mugil cephalus fish diets had no effect on serum $17 \beta-E_{2}$. These results agree with Serag El Din, Abd-El Azim, and Abd-El Fattah (2017) who found that consumption of salmon diet for 3 months had no effect on $E_{2}$ levels in adult male rats. A possible explanation may be due to that testosterone is the most abundant male sex hormone, while $17 \beta-E_{2}$ is low in males.

Also, this study showed decrease in sperm count in male rats fed with grilled tilapia and Mugil cephalus fish diets for 3 months compared with the control group, while sperm abnormalities significantly increased in male rats fed with the same diets.

These results are in harmony with those obtained by Gdoura et al. (2011) who found a significant fall in both number and motility of spermatozoa present in the cauda epididymis of male rats consuming $100 \mathrm{~g}$ wild tuna fish for 60 days. 
It is well established that the development of germ cells is dependent on testosterone and FSH. The decrease of both hormones increases germ cell apoptosis and decreases sperm count (McLachlan et al., 2002). FSH is necessary for initiation of spermatogenesis and maturation of spermatozoa, and testosterone acts on the Sertoli and peritubular cells of the seminiferous tubules and stimulates spermatogenesis (Calder, 2012). This is installed in our study which showed decrease in serum testosterone and FSH.

Another interpretation of decreased sperm count may be due to $\omega-6$ which affects spermatogenesis, by the incorporation into spermatozoa cell membrane so that the disruption of spermatogenesis at any stage of cell differentiation can decrease the total sperm count, increase the abnormal sperm count, and impair the stability of sperm chromatin or damage sperm deoxyribonucleic acid (DNA) (Mangelsdorf, Buschmann, \& Orthen, 2003).

Moreover, the ability of heavy metals to damage the neurons of the hypothalamus which is responsible for gonadotropin-releasing hormone $(\mathrm{GnRH})$ release, leading to disruption of androgen secretion from Leydig cells or inhibin B secretion (a potential marker for spermatogenesis and testicular function) from Sertoli cells (Jensen, Bonde, \& Joffe, 2006).

Histopathological studies showed that grilled tilapia and Mugil cephalus fish diets induced splitting of basement membrane of seminiferous tubules and less dense packing of spermatogenic cell with wide emptied lumen as seen in Fig. 1b-h. These results agree with Gdoura et al. (2011) who said that feeding rats with wild tuna muscle from the Gulf of Gabes in the Tunisian coast which is known to be polluted by industrial wastes resulted in (1) the lumen of the seminiferous tubules being more enlarged, (2) disintegration of the germinal epithelium, (3) detachment and degenerative changes of lining cells, (4) reduction in the number of round spermatids, and (5) significant failure of spermatid maturation and almost absence of mature spermatozoa.

As for the effect of grilled tilapia and Mugil cephalus fish diets on the histology of epididymis, the present study showed columnar lining epithelium of the epididymal tubules with reduction in the number of sperms in the lumen as seen in Fig. 2b-h. Also, grilled tilapia and Mugil cephalus fish diets showed elevation in sperm abnormalities as increased number of quasi-normal head, big head, amorphous head, banana-shaped head, hookless head, vacuolated head, deformed orientation head, acute curvature head, triangular head, detached head, bent with projection filament and neck, and coiled tail sperms as seen in Figs. $3 \mathrm{~b}-\mathrm{h}$ and 4 . These results may be due to the lowering of testosterone and FSH and defect in spermatogenesis (Gdoura et al., 2011).

\section{Conclusions}

These results may indicate that consumption of tilapia and Mugil cephalus fish diets from Moyes Sea, Lake El-Manzalah, Suez Canal, Damietta, and Kafr El-Sheikh governorate has adverse effects on male reproductive hormones and prolactin in male albino rats. Finally, we recommend that it is not safe to eat wild fish obtained from Moyes Sea, Lake El-Manzalah, and Suez Canal or farmed fish obtained from Damietta governorate and Kafr El-Sheikh which is believed to have the best aquacultures. We advise not to eat tilapia or Mugil cephalus fish diets from these areas.

\section{Abbreviations \\ AIN-93M: American Institute of Nutrition-93 for Maintenance; ANOVA: Analysis of variance; b.w.: Body weight; Cd: Cadmium; DNA: Deoxyribonucleic acid; E2: Estradiol; ELISA: Enzyme-linked immunosorbent assay; FAO: Food Agriculture Organization; FSH: Follicle- stimulating hormone; GnRH: Gonadotropin-releasing hormone; H\&E: Hematoxylin and eosin; Hg: Mercury; HSD: Hydroxysteroid dehydrogenase; LH: Luteinizing hormone; MeHg: Methyl mercury; MT: Methyltestosterone; P: Probability; Pb: Lead; PCBs: Polychlorinated biphenyls; Ppm: Parts per million; PUFAs: Polyunsaturated fatty acids; S.E.: Standard error; SPSS: Statistical Processor System Support; StAR: Steroid acute regulator; TSH: Thyroid-stimulating hormone; $\omega-6$ : Omega-6}

Availability of data and materials

The authors agree for availability of supporting data.

\section{Authors' contributions}

SOS was responsible for suggesting and planning the work, for continuous help and valuable advice in the experimental part, and for revising the manuscript. BH was responsible for the kind help in the experimental part and revision. LRA was responsible for the experimental part; all authors cooperated in writing the paper. All authors read and approved the final manuscript.

\section{Ethics approval}

This study has approved protocol from the ethical point of view and according to the Animal Welfare Act, Ain Shams University.

Consent for publication

The authors agree.

Competing interests

The authors declare that they have no competing interests.

\section{Publisher's Note}

Springer Nature remains neutral with regard to jurisdictional claims in published maps and institutional affiliations.

Received: 4 January 2018 Accepted: 4 October 2018

Published online: 17 October 2018

\footnotetext{
References

Afeiche, M.C., Gaskins, A.J., Williams, P.L., Toth, T.L., Wright, D.L., Tanrikut, C., Hauser, R. \& Chavarro, J.E. (2014). Processed meat intake is unfavorably and fish intake favorably associated with semen quality indicators among men attending a fertility. Clinic. The Journal of Nutrition, 144, 1091-1098.

Ahmad, M. H., Shalaby, A. M. E., Khattab, Y. A. E., \& Abdel-Tawwab, M. (2002), Effects of 17 a- methyltestosterone on growth performance and some physiological changes of Nile tilapia fingerlings (Oreochromis niloticus). Egyptian Journal of Aquatic Biology and Fishieries, 4, 295-311.

Ali, M. M. H. (2008). Assessment of some water quality characteristics and determination of some heavy metals in lake Manzalah, Egypt. Egyptian Journal of Aquatic Biology and Fishieries, 12, 133-154.
} 
Aravindakshan, J., Gregory, M., Marcogliese, D. J., Fournier, M., \& Cyr, D. G. (2004) Consumption of xenoestrogen-contaminated fish during lactation alters adult male reproductive function. Toxicological Sciences, 81, 179-189.

Authman, M. M. N. (2008). Oreochromis niloticus as a biomonitor of heavy metal pollution with emphasis on potential risk and relation to some biological aspects. Global Veterinaria, 2, 104-109.

Banchroft, J. D., Stevens, A., \& Turner, D. R. (1996). Theory and practice of histological techniques, (Fourth ed., ). New York, London, San Francisco, Tokyo: Churchil Living stone.

Bjorndahi, L., Söderluund, I., \& Kvist, U. (2003). Evaluation of the one-step eosinnigrosin staining technique for human sperm vitality assessment. Human Reproduction, 18, 813-816.

Bolawa, O. E., Gbenle, G. O., \& Ebuehi, O. A. T. (2014). Endocrine disruption by the consumption of fish (Tilapia oreochromis) from heavy metals polluted river sites and its reversal using zinc. International Journal of Aquaculture, 4, 85-88.

Calder, P. C. (2012). Mechanisms of action of (n-3) fatty acids. The Journal of Nutrition, 142, 592S-599S

Chattopadhyay, S., Ghosh, S., Chaki, S., Debnath, J., \& Ghosh, D. (2000). Effect of sodium arsenite on plasma levels of gonadotrophins and ovarian steroidogenesis in mature albino rats: Duration-dependent response. The Journal of Toxicological Sciences, 24, 425-431.

Domingo, J. L. (2007). Omega-3 fatty acids and the benefits of fish consumption: Is all that glitters gold? Environment International, 33, 993-998.

Encinias, C., Pateel, E., \& Poland, E. (2007). Improvement of ovulation after interaction between lead acetate and fish oil meals in female albino mice. Journal of Fertility \& Sterility, 5, 130-136.

FAO (2014). The state of world fisheries and aquaculture, (p. 223). FAO: Rome.

Gdoura, N., Abdelmouleh, A., Chaabouni, K., Ayadi, F. M., Guermazi, F., Murat, J., \& Elfeki, A. (2011). Alteration of male reproductive system in rats fed on red or white meat from tuna fish caught in the Gulf of Gabes in Tunisian coast. Environmental Chemistry Letters, 9, 273-278.

Goffin, V., Binart, N., Touraine, P., \& Kelly, P. A. (2002). Prolactin: The new biology of an old hormone. Annual Review of Physiology, 64, 47-67.

Hedayati, A., Zare, P., \& Abarghouei, S. (2012). Effect of environmental mercury on some hormonal parameters of the main mariculture fish of Persian Gulf. Global Veterinaria, 8, 43-50.

Jensen, T. K., Bonde, J. P., \& Joffe, M. (2006). The influence of occupational exposure on male reproductive function. Occupational Medicine, 56, 544-553.

Kelly, C., Santillo, D., Johnston, P., Fayad, G., Baker, K. L., \& Law, R. J. (2008). Polycyclic aromatic hydrocarbons in oysters from coastal waters of the Lebanon 10 months after the Jiyeh oil spill in 2006. Marine Pollution Bulletin, $56,1215-1233$

Lafuente, A., Cano, P., \& Esquifino, A. I. (2003). Are cadmium effects on plasma gonadotropins, prolactin, ACTH, GH and TSH levels, dose-dependent? BioMetals, 16, 243-250.

Lafuente, A., Carrace, A. G., Romero, A., \& Gano, P. (2005). Cadmium exposure differentially modifies the circadian patterns of norepinephrine and plasma LH, FSH \& testosterone levels. Toxicology Letters, 155, 87-96.

Liu, M. Y., Leu, S. F., Yang, H. Y., \& Huang, B. M. (2003). Inhibitory mechanisms of lead on steroidogenesis in MA-10 mouse Leydig tumor cells. Archives of Andrology, 49, 29-38.

Lorenzini, F., Tambara Filho, R., Gomes, R. P., Martino-Andrade, A. J., Erdmann, T. R. , \& Matias, J. E. (2012). Long-term effects of the testicular torsion on the spermatogenesis of the contralateral testis and the preventive value of the twisted testis orchiepididymectomy. Acta Cirúrgica Brasileira, 27, 388-395.

Macfadyen, G., Nasr Allah, A. M., Kenawy, D. A. R., Ahmed, M. F. M., Hebicha, H., Diab, A., ... El Naggar, G. (2011). Value-chain analysis of Egyptian aquaculture. Project report 54, (p. 84). Penang, Malaysia: The WorldFish Center.

Maier, D., Blaha, L., Giesy, J. P., Henneberg, A., Köhler, H. R., Kuch, B., ... Triebskorn, R. (2014). Biological plausibility as a tool to associate analytical data for micropollutants and effect potentials in wastewater, surface water, and sediments with effects in fishes. Water Research, 2015, 127-144.

Mangelsdorf, I., Buschmann, J., \& Orthen, B. (2003). Some aspects relating to the evaluation of the effects of chemicals on male fertility. Regulatory Toxicology and Pharmacology, 37, 356-369.

Marie, E., Lars, E., \& Anital, N. (2001). Effect of lead on the endocrine system on lead smelter workers. Archives of Environmental Health, 56, 449-455.

McLachlan, R. I., O'Donnell, L., Meachem, S. J., Stanton, P. G., de Kretser, D. M., Pratis, K., \& Robertson, D. M. (2002). Identification of specific sites of hormonal regulation in spermatogenesis in rats, monkey, and man. Recent Progress in Hormone Research, 57, 149-179.
Nagar, R. N., \& Bhattacharya, L. (2001). Effect of mercuric chloride on testicular activities in mice, Musculus albinus. Journal of Environmental Biology, $22,15-18$.

Naziri, D. (2011). Financial services for SME (small and medium-scale enterprise) aquaculture producers. Egypt case study. Draft-confidential, 25 January 2011. This report is an output from a project funded by the German Agency for Technical GTZ.

Pant, N., \& Srivastava, S. P. (2003). Testicular and spermatotoxic effects of quinalphos in rats. Journal of Applied Toxicology, 23, 271-274.

Persky, V., Turyk, M., Anderson, H. A., Hanrahan, L. P., Falk, C., Steenport, D. N., ... Freels, S. (2001). The effects of PCB exposure and fish consumption on endogenous hormones. Environmental Health Perspectives, 109, 1275-1283.

Petkovšek, S. A., Grudnik, Z. M., \& Pokorny, B. (2012). Heavy metals and arsenic concentrations in ten fish species from the Šalek lakes (Slovenia): Assessment of potential human health risk due to fish consumption. Environmental Monitoring and Assessment, 184, 2647-2662.

Ramalingam, V., Vimaladevi, V., Rajeswary, S., \& Suryavathi, V. (2003). Effect of mercuric chloride on circulating hormones in adult albino rats. Journal of Environmental Biology, 24, 401-404.

Rao, M. V., \& Sharma, P. S. N. (2001). Protective effect of vitamin E against mercuric chloride reproductive toxicity in male mice. Reproductive Toxicology, 15, 705-712.

Rebar, R. W., Erickson, G. F., \& Yen, S. S. C. (1982). Idiopathic premature ovarian failure: Clinical and endocrine characteristics. Fertility and Sterility, 37, 35-41.

Reeves, P. G., Nielson, F., \& Fahey, G. C. (1993). Purified diets for laboratory rodents: Final report of the American Institute of Nutrition ad hoc writing committee on the reformulation of the AIN-76A rodent diet. The Journal of Nutrition, 123, 1939-1951.

Risso, A., Pellegrino, F. J., Relling, A. E., \& Corrada, Y. (2016). Effect of long-term fish oil supplementation on semen quality and serum testosterone concentrations in male dogs. International Journal of Fertility \& Sterility, 10, 223-231.

Rivero-Wendt, C. L., Borges, A. C., Oliveira-Filho, E. C., Miranda-Vilela, A. L., Ferreira, M. F., \& Grisolia, C. K. (2014). Effects of 17alpha-methyltestosterone on the reproduction of the freshwater snail Biomphalaria glabrata. Genetics and Molecular Research, 13, 605-615.

Rizkalla, E. H., Haleem, H. H., Abdel-Halim, A. M. M., \& Youssef, R. H. (2004). Evaluation of using 17a-methyl testosterone for monosex Oreochromis niloticus fry production. Journal-Egyptian German Society of Zoology, 43, 315-335.

Rose, M. P. (1998). Follicular stimulating hormone international standards and reference preparations for the calibration of immunoassays and bioassays. Clinica Chimica Acta, 273, 103-117.

Rothuis, A., Pieter van Duijn, A., Roem, A., Ouwehand, A., Piji, W. \& Rurangwa, E. (2013). Aquaculture business opportunities in Egypt. Wageningen, Wageningen UR (University \& Research centre). LEl report 2013-039, IMARES report C091/13.

Sadem, D., Sela, E., \& Hexter, C. S. (1979). Enzyme immunoassay for the quantitative determination of $17 \beta$-estradiol in human serum and plasma. Journal of Immunological Methods, 28, 125-131.

Serag El Din, O. S., Abd-El Azim, B. H., \& Abd-El Fattah, N. (2017). Ameliorating role of salmon diet on water disinfection by products on fertility of the male albino rats. Ciencia e Tecnica Vitivinicola, 32, 24-29.

Shokr, E. A. (2015). Effect of lead on blood hormones measurements of Nile tilapia. Journal of Chemical and Pharmaceutical Research, 7, 1957-1962.

Stocco, D. M., Wang, X., Jo, Y., \& Manna, P. R. (2005). Multiple signaling pathways regulating steroidogenesis and steroidogenic acute regulatory protein expression: More complicated than we thought. Molecular Endocrinology, 11, 2647-2659.

Tong, M. H., Christenson, L. K., \& Song, W. C. (2004). Aberrant cholesterol transport and impaired steroidogenesis in Leydig cells lacking estrogen sulfotransferase. Endocrinology, 145, 2487-2497.

Turkes, A., et al. (1979). Enzyme immunoassay for the quantitative determination of total testosterone in human serum and plasma. The Journal of Endocrinology, 81, 165.

Wathes, D. C., Abayasekara, D. R., \& Aitken, R. J. (2007). Polyunsaturated fatty acids in male and female reproduction. Biology of Reproduction, 77, 190-201.

Webb, M. A. H., Feist, G. W., Fitzpatrick, M. S., Foster, E. P., Schreck, C. B., Plumlee, M., ... Gundersen, D. T. (2006). Mercury concentrations in gonad, liver and muscle of white sturgeon Acipenser transmontanus in the lower Columbia river. Archives of Environmental Contamination and Toxicology, 50, 443-451. 
Wim, V., Issabelle, S., Stefan, D., \& John, V. (2007). Consumer perception versus scientific evidence of farmed and wild fish: Exploratory insights for Belgium. Aquaculture International, 15, 121-136.

Yeste, M., Barrera, X., Coll, D., \& Bonet, S. (2011). The effects on boar sperm quality of dietary supplementation with omega-3 polyunsaturated fatty acids differ among porcine breeds. Theriogenology, 76, 184-196.

Yue, G. H., Lin, H. R., \& Li, J. L. (2016). Tilapia is the fish for next-generation aquaculture. International Journal of Marine Science and Ocean Technology, 3, 11-13.

Zheng, Y., Qiu, L., Fan, L., Meng, S., Song, C., Bing, X., \& Chen, J. (2016). Effect of 17a-methyltestosterone (MT) on oxidation stress in the liver of juvenile GIFT tilapia, Oreochromis niloticus. Springer Plus, 5, 338-345.

\section{Submit your manuscript to a SpringerOpen ${ }^{\circ}$ journal and benefit from:}

- Convenient online submission

- Rigorous peer review

- Open access: articles freely available online

High visibility within the field

- Retaining the copyright to your article

Submit your next manuscript at $\boldsymbol{\nabla}$ springeropen.com 